\title{
Enhance Nutrition Security through Quality Protein Maize (QPM)
}

\author{
Poonam Kundu*, Rajesh Dahiya and Beena Yadav \\ Department of Extension Education \& Communication Management CCS Haryana \\ Agricultural University, Hisar 125004, Haryana, India \\ *Corresponding author
}

\section{A B S T R A C T}

\section{Keywords}

Agriculture, Raw ingredients, Crop, Rice, Wheat,

Protein, Cereals, Maize

Article Info

Accepted:

04 October 2019

Available Online:

10 November 2019
Realizing the importance of coarse cereals, it has become essential now to justify their role in the food and nutritional security of India; millets are super grains and were used extensively but as a result of urbanization and large scale production and availability of cereals like wheat, rice and corn. In India maize is emerging as third most important crop after rice and wheat. Its importance lies in the fact that it not only used for human food and animal feed but at the same time it is also widely used for corn starch industry, oil production, baby corn, etc. Maize holds a prominent position in Indian Agriculture. The technology of acceptable maize based products can be taken up by house wives at household level as the raw ingredients are available. Various processing techniques will not only help in improving the availability of nutrients but also enhance the shelf life of maize flour. To boost the consumption of maize, it become necessary to develop value added products which can be prepared at home scale as well as commercial scale keeping these facts in view intervention on five selected products were organized in three villages by covering 90 respondents. Perceived feasibility was worked out on five parameters. Knowledge acquisition was found 86.24 percent and 84.92 percent respectively for all products.

\section{Introduction}

India has abundant crop diversity despite varied agricultural assets in terms of soil, rainfall and climate. A variety of coarse cereals are grown throughout the length and breadth of the country but mostly as rain fed crop and covering lesser area as compared to rice and wheat. These coarse cereals are utilized in the regions where they are grown.
The rural and urban people also like them as they are nutritionally rich and proved good for human health. Millets in general, contain substantially high amount of fat, fiber and minerals as compared to fine cereals. Therefore, millets are now being pronounced as nutria-cereals and miracle grains. Maize is an important coarse grain cereal in India. Among cereals, maize in India ranks fifth in total area and third in total production and 
productivity. Several million people, particularly in the developing countries, derive their protein and calorie requirements from maize. India plays a prominent role in world maize market. In the year 2013-14, export of maize reached a record of 5five million tones which was 24 percent higher as compared to the previous year.

Various processing techniques will not only help in improving the availability of nutrients but also enhance the shelf life of maize flour. To boost the consumption of maize, it become necessary to develop value added products which can be prepared at home scale as well as commercial scale with the help of on farm trials conducted on selected appropriate products for acceptance among rural masses. Keeping in mind the present study was undertaken to create awareness among rural women as value added products of maize, on farm trials on value added products of maize an adoption feasibility of maize products.

\section{Materials and Methods}

The present study was conducted in Hisar district of Haryana state. Three villages namely Kharar, Singran and Chinder were selected randomly for intervention programme. Study was conducted in anganwadi centers of each village. The sample comprised of 90 rural women, 30 rural women from each village who were regular visitors of anganwadi centers. The experiment was conducted into two phases. During first phase, value added products of maize were selected for intervention with the help of experts of Foods and Nutrition Department, College of Home Science, CCSHAU, Hisar. Consequently, five products with the combination of maize flour, gram flour and wheat flour namely ladoo, matar, halwa, sev and pakora were obtained for further dissemination. In phase-II- Intervention package comprised of rapport building, lectures, demonstration, literature and focused group discussion were implemented in all the three villages by covering 90 respondents. All five products were prepared and distribution among the beneficiaries for sensory evaluation. Knowledge and skill acquisition were assessed before and after implementation of the program me. Perceived feasibility was assessed on four attributes of technology.

\section{Results and Discussion}

Five maize products viz., ladoo, halwa, matar, sev and pakora were demonstrated and gain in knowledge was assessed regarding ingredient and recipe of respective products. It can be revealed from table 1 that the respondents acquired very high knowledge regarding ingredients of different maize products.

Acquired knowledge was maximum regarding ingredients of halwa (94.66\%) followed by matar $(89.81 \%)$, sev $(88.19 \%)$, pakora $(87.63 \%)$ and ladoo $(86.11 \%)$ respectively. As far as procedure regarding different product preparation is concerned it was noted that the women acquired more than 80 percent knowledge about four products viz. ladoo $(87.11 \%)$, halwa $(86.66 \%)$, pakora $(84.88 \%)$ and sev $(85.55 \%)$, however knowledge gain regarding QPM matar preparation was only $58.14 \%$.minimum $(58.14 \%)$.

Overall knowledge gain regarding ingredients required for preparation of recommended QPM products was 88.95 percent and 86.24 percent gain in knowledge of respondents was observed regarding preparation method of the recommended products. The results are in with Rai (2011) and Rekha (2015).

In terms of skill acquisition as given in table 2 it was found that 84.92 percent skill was acquired regarding QPM products. Productswise skill acquisition indicated that maximum skill was gained regarding ladoo (95.33\%) 
followed by pakora (91.11\%), halwa (87.40\%), matar (77.77\%) and sev (69.44\%) respectively.

Perceived adoption feasibility of women regarding QPM products

It was found that no crystal clear trend was observed regarding relative advantage of QPM products as scattered responses were obtained. Majority of the women were undecided about its initial cost (77.77\%), use consistency
(66.66\%) and time saving feature (77.77\%) about monetary benefit and multiple use potential the responses were equally divided under three response categories. Use consistency of QPM products was ranked first (M.S. 2.33) followed by low initial cost \& time saving (M.S 2.22 each) and monetary benefit \& multiple use potential (M.S 2.00 each) the mean score values again indicated that majority of the respondents had neutral perception about relative advantage of QPM products (Table 3 ).

Table.1 Knowledge acquisition of women regarding QPM maize products

\begin{tabular}{|c|c|c|c|}
\hline S.No. & Products & Ingredients & Procedure \\
\hline & & Score (Percentage) & Score (Percentage) \\
\hline 1 & Ladoo & $465(86.11 \%)$ & $392(87.11 \%)$ \\
\hline 2 & Halwa & $426(94.66 \%)$ & $234(86.66 \%)$ \\
\hline 3 & Matar & $485(89.81 \%)$ & $314(58.14 \%)$ \\
\hline 4 & Pakora & $631(87.63 \%)$ & $382(84.88 \%)$ \\
\hline 5 & Sev & $635(88.19 \%)$ & $308(85.55 \%)$ \\
\hline & Total & $\mathbf{2 6 4 2 ( 8 8 . 9 5 \% )}$ & $\mathbf{1 6 3 0}(\mathbf{8 6 . 2 4 \%})$ \\
\hline
\end{tabular}

Table.2 Skill acquisition of women regarding QPM products

\begin{tabular}{|c|c|c|c|}
\hline S.No. & Products & Score & Percentage \\
\hline 1 & Ladoo & 429 & 95.33 \\
\hline 2 & Halwa & 236 & 87.40 \\
\hline 3 & Matar & 280 & 77.77 \\
\hline 4 & Pakora & 410 & 91.11 \\
\hline 5 & Sev & 250 & 69.44 \\
\hline & Total & 1605 & 84.92 \\
\hline
\end{tabular}


Table.3 Perceived adoption feasibility of women regarding QPM products

\begin{tabular}{|c|c|c|c|c|c|c|c|}
\hline \multirow[t]{2}{*}{ S. No. } & \multirow[t]{2}{*}{ Attributes } & \multicolumn{3}{|c|}{ Response Categories } & \multirow{2}{*}{$\begin{array}{l}\text { Total } \\
\text { score }\end{array}$} & \multirow{2}{*}{$\begin{array}{l}\text { Mean } \\
\text { score }\end{array}$} & \multirow[t]{2}{*}{ Rank } \\
\hline & & Agree & Undecided & Disagree & & & \\
\hline \multicolumn{8}{|c|}{ Relative advantage } \\
\hline 1 & Low initial cost & $20(22.2)$ & $70(77.7)$ & $00(00)$ & 200 & 2.22 & II \\
\hline 2 & Monetary benefits & $30(33.3)$ & $30(33.3)$ & $30(33.3)$ & 180 & 2.00 & $1 \mathrm{~V}$ \\
\hline 3 & Consistency of use & $30(33.3)$ & $60(66.6)$ & $00(00)$ & 210 & 2.33 & I \\
\hline 4 & Time saving & $20(22.2)$ & $70(77.7)$ & $00(00)$ & 200 & 2.22 & II \\
\hline 5 & Multiple use potential & $30(33.3)$ & $30(33.3)$ & $30(33.3)$ & 180 & 2.00 & $1 \mathrm{~V}$ \\
\hline \multicolumn{8}{|c|}{ Compatibility } \\
\hline 1 & Cultural compatibility & $30(33.3)$ & $60(66.6)$ & $00(00)$ & 210 & 2.33 & I \\
\hline 2 & Physical compatibility & $30(33.3)$ & $60(66.6)$ & $00(00)$ & 210 & 2.33 & I \\
\hline 3 & Situational compatibility & $30(33.3)$ & $30(33.3)$ & $30(33.3)$ & 180 & 2.00 & II \\
\hline 4 & Social compatibility & $30(33.3)$ & $30(33.3)$ & $30(33.3)$ & 180 & 2.00 & II \\
\hline 5 & Relational compatibility & $15(16.6)$ & $18(20.0)$ & $57(63.3)$ & 138 & 1.53 & III \\
\hline \multicolumn{8}{|c|}{ Simplicity / complexity } \\
\hline 1 & Cognitive simplicity & 70(77.7) & $20(22.2)$ & $00(00)$ & 250 & 2.77 & II \\
\hline 2 & Application simplicity & $80(88.8)$ & $10(11.1)$ & $00(00)$ & 260 & 2.88 & I \\
\hline 3 & Resource simplicity & $00(00)$ & $10(11.1)$ & $80(88.8)$ & 100 & 1.11 & IV \\
\hline 4 & Reversibility & $90(100.0)$ & $00(00)$ & $00(00)$ & 270 & 3.00 & V \\
\hline 5 & Increase in efficiency & 10(11.1) & $70(77.7)$ & 10(11.1) & 180 & 2.00 & III \\
\hline \multicolumn{8}{|c|}{ Practicability } \\
\hline 1 & Communicability & $70(77.7)$ & $20(22.2)$ & $00(00)$ & 250 & 2.77 & IV \\
\hline 2 & Visibility & 70(77.7) & $20(22.2)$ & $00(00)$ & 250 & 2.77 & IV \\
\hline 3 & Demonstrability & $80(88.8)$ & $10(11.1)$ & $00(00)$ & 260 & 2.88 & III \\
\hline 4 & Triaibility & $90(100.0)$ & $00(00)$ & $00(00)$ & 270 & 3.00 & I \\
\hline 5 & Provision of & $90(100.0)$ & $00(00)$ & $00(00)$ & 270 & 3.00 & II \\
\hline & modification & & & & & & \\
\hline
\end{tabular}

(Figures in parenthesis indicate percentage) 
Perception of women about various compatibilities of QPM products was similar to that of relative advantage i.e. responses of women fluctuated under three response categories. In terms of mean score values physical and cultural compatibility (M.S 2.33 each) was comparatively more than situational \& social compatibility (MS 2.00 each) and relational compatibility of QPM products was perceived to be minimum (M.S 1.53). Recipes of QPM products were perceived to be easily understand able and triable at household level by majority of the respondents as indicated by positive perception about cognitive $(77.77 \%)$ and application simplicity (88.88\%) of QPM products. Resource simplicity of QPM products was perceived by not even a single respondent due to non availability QPM in local market. Reversibility was ranked first (M.S 3.00) followed by application simplicity (M.S 2.88) cognitive simplicity (M.S 2.77) increased efficiency (M.S 2.00) and resource simplicity (M.S 1.11) were negatively perceived.

Majority of the respondents perceived QPM products as communicable (77.77\%), yielding visible results $(77.77 \%)$, demonstrable $(88.88 \%)$ hundred percent tribal and having complete scope of modification. Triability \& scope of modification in QPM products were ranked most prominent parameters of practicability (M.S 3.00 each) as both of these two parameters of practicability were positively perceived by all the selected respondents. These two were followed by demonstrability (M.S 2.88) and communicability \& visibility of results (M.S. 2.77each). Results are in consonance with the findings of Malik. (2015) and Dahiya, etal. (2016)

In the end it can be concluded that QPM products are physical and culturally compatible, with low initial cost and in consistence to use.
All products are simple and tribal with a scope of further modification according to one's own consumption and taste.

\section{References}

Dahiya, R and Kawatra, A. (2016) Adoption feasibility of pearl millet products among farm women. Paper published in $5^{\text {th }}$ National Seminar on Coarse Cereals Development-Challenges and Opportunities in the Country, organized by Directorate of Millets Development Jaipur on March 20-21, 2016.

Murdia, L.K., Nikita Wadhwar, Preet, Bajpai and Seema, Sekhawat. 2016. Value addition in maize. Paper published in $5^{\text {th }}$ National Seminar on Coarse Cereals Development-Challenges and Opportunities in the Country, organized by Directorate of Millets Development Jaipur on March 20-21, 2016.

Rai, S., Kaur, A and Singh, B.(2011) Quality characteristics of gluten free cookies prepared from different flour combinations. Paper published in journal of food science technologies on Vol -(6): 786-789.

Rekha, (2015) Feasibility of value added products of maize as an enterprise for rural women. M.Sc. thesis, CCSHAU, Haryana Agricultural University, Hisar.

Malik, P. (2014). Feasibility of value added products of pearlmillet as an enterprise for rural women, M.sc. thesis, CCSHAU, Haryana Agricultural University, Hisar.

Yadav, B., Dahiya, R and Kundu, P. (2009) Action Research pertaining to training of rural women and adolescent girls regarding improved home practices. Research Report, CCSHAU, Haryana Agricultural University, Hisar.

\section{How to cite this article:}

Poonam Kundu, Rajesh Dahiya and Beena Yadav. 2019. Enhance Nutrition Security through Quality Protein Maize (QPM). Int.J.Curr.Microbiol.App.Sci. 8(11): 80-84. doi: https://doi.org/10.20546/ijcmas.2019.811.009 